\title{
АНГЛІЙСЬКА МОВА - ОДНА 3 НАЙВАЖЛИВІШИХ ВИМОГ СУЧАСНОГО СВІТУ
}

\author{
КУЗІВ Ірина-Марія Іванівна - студентка 4-го курсу Дрогобицького \\ фахового коледжу нафти та газу, студентка 2-го курсу Дрогобицького державного \\ педагогічного університету імені Івана Франка \\ КУЗІВ Іван Іванович - студент 5-го курсу Івано-Франківського \\ національного технічного університету нафти та газу
}

DOI 10.32782/NP.2021.4.25

Знання іноземних мов - ие ключ до успіху в сучасному світі, де спілкування іноземними мовами та обробка величезних обсягів інбормачї̈ набуває все більшого значення. Інтерес до вивчення мов традииійно великий, бо, перефразовуючи відомий вислів, можна сміливо сказати, що той, хто володіє мовами, володіє світом.

Загалом людина, яка володіє мовами, різнобічно розвинута особистість, володіє крашими здібностями до вивчення нового, вільніша та більш впевнена у спілкуванні 3 людьми.

Съогодні сучасні вимоги до фбахівиів з кожним роком зростають $i$ не включають не тільки високий рівень знань $і$ навичок за бахом, а й знання іноземної мови на належному рівні. Це пов'язано з тим, що сучасний спеціаліст отримує нову ббахову інбормаиін через іноземні джерела. Съогодні навчання іноземної мови сприяе реалізациі таких напрямків професійної діяльності, як ознайомлення з новими технологіями, науковими гіпотезами, видатними інновачіями в галузі техніки; налагодження контактів з іноземними партнерами, бірми, підприємства, навчальні заклади; підвищення рівня пробесійної компетентності спеціалістів. Володіння іноземною мовою - ие вже не ознака престижу, а необхідність для сучасного спещуіаліста.

Ключові слова: англійсъка мова, спеизаліст, юрист, економіст, IT-спечіаліст, нафбтогазовий спеціаліст, освіта, побудова кар'єри, навчання.

\section{Постановка проблеми}

Сьогодні сучасні вимоги до фахівців 3 кожним роком зростають і включають не тільки високий рівень знань і навичок за фахом, а й знання іноземної мови на належному рівні. Це пов'язано з тим, що сучасний спеціаліст отримує нову фахову інформацію через іноземні джерела. Сьогодні навчання іноземної мови сприяє реалізації таких напрямків професійної діяльності, як ознайомлення 3 новими технологіями, науковими гіпотезами, видатними інноваціями в галузі техніки; налагодження контактів 3 іноземними партнерами, фірми, підприємства, навчальні заклади; підвищення рівня професійної компетентності спеціалістів. Володіння іноземною мовою - це вже не ознака престижу, а необхідність для сучасного спеціаліста.

\section{Аналіз дослідження}

Аналіз досліджень українських та зарубіжних джерел показав, що англійська мова $\epsilon$ офіційною мовою міжнародного бізнесу та торгівлі, Інтернету та технологій, науки та мистецтва. 80\% ділового мовного простору займає вона. Кожен з нас все частіше стикається з цим у спілкуванні з партнерами по роботі й на відпочинку. Англійська мова використовується при заповненні анкет, резюме, у діловому та приватному листуванні. Знання англійської - це вже не дивовижна навичка, а необхідність. Сьогодні іiї навчають у садочках, школах, університетах, не кажучи вже про численні курси та 
тренінги. А в деяких країнах навіть математику та деякі інші шкільні предмети викладають англійською.

Місце англійської мови як мови міжнародного спілкування в перспективі політичних, соціальних, управлінських та філософських наук досліджувалося низкою вчених, зокрема Г. Дивнич, О. Домнич,О. Камишлів, Н. Пелагеш.

Англійська мова сьогодні має статус мови міжнародного спілкування, і люди, які вільно нею володіють, можуть отримати престижну роботу, яка буде джерелом стабільного доходу. Іноземна мова, зокрема, стає все більш актуальною в сучасному суспільстві як засіб міжкультурної комунікації між професіоналами юридичних, економічних, IT та нафтогазових професій.

Юрист повинен говорити вільно і правильно, вміти знаходити слова, володіти усним і письмовим мовленням, тому що йому необхідно використовувати відповідну термінологію для подання фактів, переконування, легкого пояснення змісту документа клієнту та в суді. А ще краще, якщо юрист зможе зробити це англійською. Навіть маючи досконале знання англійської мови, потрібно знати спеціальні терміни та правила їх використання, адже вони відіграють важливу роль і вимагають додаткових зусиль для вивчення та засвоєння. Навіть носії мови змушені додатково вивчати лексику своєї спеціальності.

Юридичний працівник повинен вміти використовувати певні синтаксичні конструкції, віртуозно будувати пропозиції, шукати винятки та невідповідності в законодавчих актах. Юридичний працівник має визначити, які головні риси, якості та навички потрібно розвивати у собі, щоб стати справжнім професіоналом.

Професійна англійська для працівників нафтогазової промисловості спрямована на підвищення комунікативних навичок фахівців у міжнародному діловому середовищі нафтогазової галузі, вивченні різноманітних професійних тематик, пов’язаних iз нафтогазовою галуззю і прогнозуванням видобутку нафти та газу та розвитку галузі в цілому.
Іноземна мова справді потрібна фахівцям нафтогазової промисловості, але не загальна англійська, а саме - технічна спеціалізована англійська мова. Сьогодні практично всі нафтові компанії використовують у роботі комп'ютерні програми 3 англомовним інтерфейсом для створення 3D-візуалізації родовищ нафти та газу. Знання технічної англійської мови необхідно фахівцям нафтогазової промисловості, щоб бути конкурентоспроможними на ринку праці як національного, так і міжнародного рівня.

Фінансовий світ - це світ, у якому дуже важливо отримувати швидкий доступ до актуальної інформації. Ось тільки актуальна інформація найчастіше доступна саме англійською мовою. Крім того, налагоджувати ділові контакти з іноземними партнерами вам навряд чи вдасться, володіючи тільки рідною мовою. Економісти, як правило, обирають один з курсів англійської: «Англійська для фінансистів», «Англійська для бізнесменів».

За останні 10-15 років вітчизняний ринок праці перенаситився всілякими економістами та фінансистами. Вважається, що це надійна, стабільна професія. Справді, фахівці з цієї галузі потрібні, але роботодавцю часом складно зупинити свій вибір на комусь конкретному, резюме у всіх однакові: «народився-вчився». У хід йде порівняння переваг кандидатів. Чи треба говорити про те, що знання англійської може стати вирішальним у вашій кар'єрі. Крім цього, у нашій країні з кожним днем зростає частка банків 3 іноземним капіталом. Мінімум раз на рік інвестори особисто відвідують фінансові установи 3 перевірками. Тільки фахівець зі знанням англійської зможе пояснити результати фінансової звітності, провести презентацію або нараду.

B IT-сфері без знання англійської робити нічого. Сувора правда життя: не володіючи мовою, фахівці цієї галузі не зможуть працювати навіть у вітчизняних компаніях, що тут говорити про міжнародні корпорації.

По-перше, створення сайту або його тестування передбачає тісну роботу 3 ан- 


\section{Дискусії, обговорення, актуально}

глійським (починаючи від найпростіших назв кольорів і форм до складних термінів).

По-друге, технічне завдання (Т3) часто пишеться саме англійською.

Крім того, сфера інформаційних технологій швидко розвивається, тому корисно буде відвідувати освітні курси англійської мови. Фахівці, які обрали сферу ІТ-технологій, мають ідеально знати як розмовну, так і технічну англійську мову.

\section{Висновок}

Знати англійську мову сьогодні абсолютно необхідно для кожної освіченої людини й гарного фахівця. Що ж стосується кар'єри людини, знайти престижну роботу без знання англійської мови ще можливо, але все складніше. Роботодавці вважають за краще фахівців зі знанням англійської мови. Та й кар'єрний ріст вам буде забезпечений, завжди роботодавець віддасть перевагу вам фахівця, який вміє говорити міжнародною мовою. Особливо важлива англійська мова для ефективної роботи бізнесу, оскільки багато наших фірм співпрацюе з іноземними партнерами.

\section{Мiтература}

1. Бубнова Д.В. Аудіювання як засіб навчання іншомовного ділового спілкування / Д.В.Бубнова // Гуманітарна освіта в технічних вищих навчальних закладах: Збірник наукових праць Гуманітарного Інституту НАУ. - К.: ІВЦ Держкомстату України, 2003. - Вип. 6. - С.35-42

2. Дегтярьова Ю.В. Методика навчання студентів вищих немовних навчальних закладів читання англійською мовою для ділового спілкування: на здобуття наук. ступеня канд. пед. наук: 13.00.02 «теорія та методика навчання : германські мови»/ Ю.В.Дегтярьова. - Київ. - 2006. - 22 с.

3. Корнєва 3.М. Методика навчання майбутніх економістів англійського ділового мовлення на основі технології занурення: автореф. дис. на здобуття наук. ступеня канд. пед. наук: спец. 13.00.02 «теорія та методика навчання: германські мови»/ 3.М.Корнева - К., 2006. - 21с.
4. Малюська 3.В. Типові ситуації ділового спілкування для спеціалістів з економіки / З.В.Малюська // Вісник Житомирського державного університету ім.І.Франка, 2006. - Вип. 29. - С.96-99

5. Огурцова О.ภ. Навчання ділової англійської мови 3 використанням Інтернет-ресурсів / О.Л.Огруцова // Збірник наукових праць “Викладання мов у вищих навчальних закладах освіти на сучасному етапі. Міжпредметні зв'язки. Наукові дослідження. Досвід. Пошуки". - Харків: Константа, 2006. - Вип.10. - С.50-56

\section{REFERENCES}

1. Bubnova DV Listening as a means of teaching foreign language business communication / DV Bubnova // Humanitarian education in technical higher educational institutions: Collection of scientific works of the Humanitarian Institute of NAU. - Kyiv: IPC of the State Statistics Committee of Ukraine, 2003. - Issue. 6. - P.35-42

2. Degtyareva Yu.V. Methods of teaching students of higher non-language educational institutions reading in English for business communication: for science. degree of Cand. ped. Sciences: 13.00.02 "Theory and methods of teaching: Germanic languages" / YV Degtyareva. - Kyiv. - 2006. - 22 p.

3. Korneva ZM Methods of teaching future economists of English business speech on the basis of immersion technology: author's ref. dis. for science. degree of Cand. ped. Science: special. 13.00.02 "Theory and methods of teaching: Germanic languages" / ZM Korneva - K., 2006. - 21 p.

4. Malyuska ZV Typical situations of business communication for specialists in economics / ZV Malyuska // Bulletin of Zhytomyr State University named after I. Franko, 2006. - Issue. 29. - p.96-99

5. Ogurtsova OL Teaching business English with the use of Internet resources / OL Ogrutsova // Collection of scientific works "Teaching languages in higher education at the present stage. Cross-curricular links. Scientific research. Experience. Search". - Kharkiv: Konstanta, 2006. - Issue 10. p.50-56 


\section{SUMMARY}

Knowledge of foreign languages is the key to success in today's world, where communication in foreign languages and the processing of vast amounts of information is becoming increasingly important. Interest in the study of languages is traditionally great because to paraphrase a wellknown expression, we can safely say that those who speak languages own the world.

In general, a person who speaks languages is a well-rounded person, has better abilities to learn something new, is freer and more confident in communicating with people.

Today, modern requirements for professionals are growing every year and do not include not only a high level of knowledge and skills in the speciality but also knowledge of a foreign language at the appropriate level. This is due to the fact that the modern specialist receives new professional information through foreign sources. Learning foreign languages today contributes to the implementation of such areas of professional activity as acquaintance with new technologies, scientific hypotheses, outstanding innovations in the field of technology; establishing contacts with foreign partners, companies, enterprises, educational institutions; increasing the level of professional competence of specialists. Knowledge of a foreign language is no longer a sign of prestige, but a necessity for a modern specialist.

Keywords: English, specialist, lawyer, economist, IT specialist, oil and gas specialist, education, career-building, training

\section{CONCLUSION}

Knowing English today is absolutely necessary for every educated person and a good specialist. As for a person's career, finding a prestigious job without knowledge of English is still possible, but increasingly difficult. Employers prefer professionals with knowledge of English. Yes, and career growth will be provided for you, the employer will always prefer a specialist who can speak international languages. English is especially important for effective business, as many of our companies work with foreign partners. 